Zeszyty Naukowe Szkoły Głównej Gospodarstwa Wiejskiego w Warszawie

Problemy Rolnictwa Światowego tom 18 (XXXIII), zeszyt 2, 2018: 117-129

DOI: $10.22630 /$ PRS.2018.18.2.39

Józef Kania $^{1}$, Wiesław Musial ${ }^{2}$

${ }^{1}$ Państwowa Wyższa Szkoła Zawodowa w Tarnowie

${ }^{2}$ Uniwersytet Rolniczy im. Hugona Kołłąaja w Krakowie

\title{
Istota kreacji wartości dodanej w rolnictwie i na obszarach wiejskich
}

\section{The Essence of Creating Value-Added in Agriculture and in Rural Areas}

\begin{abstract}
Synopsis. Celem opracowania jest próba poszerzenia sposobu definiowania pojęcia wartości dodanej w rolnictwie i na obszarach wiejskich, głównie w oparciu o literaturę przedmiotu. W pierwszej kolejności odniesiono się do usytuowania tego pojęcia w kontekście ekonomii rolnictwa, a następnie różnych procesów, które zachodzą lub zachodzić powinny na obszarach wiejskich, kreując lub warunkując oczekiwane, pozytywne efekty, które nazwano wartością dodaną. Następnie przeanalizowano tworzenie wartości dodanej w rolniczym łańcuchu dostaw, mając na uwadze stare i nowe podejście do jej tworzenia. Analizę przypadku przeprowadzono dla spółki „Owoc Łącki” i poddano ocenie sposoby tworzenia wartości dodanej i formę integracji producentów owoców. Efektem analizy jest przedstawienie wielości i różnorodności definiowania oraz opisu uwarunkowań tworzenia wartości dodanej. Zaprezentowane przykłady, praktyki i podejścia w podnoszeniu wartości dodanej stanowić mogą inspirację dla doradców, a zwłaszcza rolników poszukujących nowych modeli biznesowych, by zwiększyć w ten sposób swoje dochody.
\end{abstract}

Słowa kluczowe: wartość dodana w rolnictwie, kreowanie wartości dodanej, integracja pionowa, łańcuch dostaw żywności

\begin{abstract}
The aim of the study is to broaden the definition of the added-value concept in agriculture and in rural areas. To start, reference was made to the location of this concept in relation to the economics of agriculture and then to the various processes that occur or should occur in rural areas creating or conditioning the expected positive effects, which were called the Value-added. Then, the creation of added value in the agricultural supply chain was analyzed with an old and new approach to its creation. The case analysis was conducted for the "Owoc Łącki" company, which assessed the ways of creating added value and the form of integration of fruit producers. The effect of the analysis is the multiplicity and diversity of defining and describing conditions for the creation of added value. The presented examples, practices and approaches in increasing the added value can be an inspiration for advisors, especially farmers looking for new business models, thus increasing their income.
\end{abstract}

Key words: value-added in agriculture, creation of the value-added, vertical integration, food supply chain

JEL Classification: M21, P13, O31, Q13

\footnotetext{
${ }^{1}$ dr hab. inż. prof. PWSZ, ul. Mickiewicza 8, 33-100 Tarnów, e-mali: jozef.kania@ur.krakow.pl; https://orcid.org/0000-0001-9102-4005

${ }^{2}$ prof. dr hab. inż., Aleje Mickiewicza 21,31-120 Kraków, e-mail: rrmusial@cyf-kr.edu.pl; https://orcid.org/0000-0002-8213-4859
} 


\section{Wprowadzenie}

Problemy, jakie stoją współcześnie przez rolnictwem i rozwojem obszarów wiejskich w Polsce, są wielkim wyzwaniem, ale także ważnym polem obserwacji naukowych i poszukiwania konstruktywnych wzorców czy też sposobów rozwiązywania różnych kwestii. Przemiany systemowe, jakie zachodziły (i nadal zachodza) w rolnictwie po roku 1990, mają zdecydowanie zróżnicowane i wysoce niejednorodne wektory oddziaływania. Te same bodźce czy też instrumenty skierowane na wieś i rolnictwo rozdrobnione strukturalnie i agrarnie oraz rolnictwo o dużej koncentracji kapitału przynoszą odmienne, a nawet skrajnie różne efekty, zarówno w odniesieniu do zamierzeń ich kreatora, jak też ich realizatora czy adresata. Różna jest też szybkość i skuteczność ich oddziaływania, co $\mathrm{w}$ rolnictwie weryfikowane jest dodatkowo poprzez długi czas produkcji wynikający $\mathrm{z}$ cykli przyrodniczych. Często cele kreowanej polityki gospodarczej czy też wspólnej polityki rolnej są niejednoznaczne, niezbyt czytelne, a nawet wewnętrznie sprzeczne, gdyż jest ich zbyt wiele i są kierowane łącznie do różnych adresatów, u których mają zrealizować odrębne przemiany. Stąd ważne jest, aby trafnie odszukiwać, gdzie, w jakich obszarach problemowych, strukturach instytucjonalnych, subregionach, a szczególnie podmiotach gospodarczych można, poprzez celowo kreowane zmiany i podejście innowacyjne, uzyskiwać taniej i prościej wartość dodaną. Może być ona kreowana poprzez optymalną organizację produkcji, wzrost jej skali, efektywnie lokowane nakłady lub trafność i adekwatność rynkową produkcji rolnej. W realiach polskich szczególnie duże możliwości uzyskania wartości dodanej w rolnictwie tkwią właśnie w koncentracji produkcji osiaganej poprzez różne jej spektrum, tj. koncentracji ziemi, kapitału produkcyjnego i pracy.

Drugim obszarem wielkich rezerw, a więc pozyskania wartości dodanej, jest relatywnie niezbyt skomplikowana organizacyjnie różnorodna współpraca wzajemna rolników w zakresie poprawy efektywności pozyskania produktu finalnego, który będzie atrakcyjny dla przetwórstwa. Duże, a być może największe możliwości tworzenia wartości dodanej tkwią $\mathrm{w}$ różnorodnych, twórczych możliwościach jej kreacji na całej długości i w różnych podmiotach łańcucha dostaw. Współcześnie takie możliwości powstają w zakresie nowego „zdobywania” przez rolników rynków lokalnych oraz rynków miejskich i wpisywania się w miejskie strategie żywnościowe. Ważne jest tu poszukiwanie najsłabszych ogniw łańcuchów dostaw i ewentualne wsparcie ich środkami publicznymi. Nowe możliwości można dostrzec także w zakresie inteligentnej specjalizacji gospodarstw skooperowanych z różnymi ogniwami przetwórstwa rolno-spożywczego przy współpracy z placówkami naukowymi (Inteligentne..., 2017).

Celem opracowania jest próba poszerzenia sposobu definiowania pojęcia wartości dodanej w rolnictwie i na obszarach wiejskich, głównie w oparciu o literaturę przedmiotu. $\mathrm{W}$ pierwszej kolejności odniesiono się do usytuowania tego pojęcia $\mathrm{w}$ odniesieniu do ekonomii rolnictwa, a następnie do różnych procesów, które zachodzą lub zachodzić powinny na obszarach wiejskich, kreując lub warunkując oczekiwane, pozytywne efekty, które nazwano wartością dodana. Następnie przeanalizowano tworzenie wartości dodanej w rolniczym łańcuchu dostaw, mając na uwadze stare i nowe podejście do jej tworzenia. Analizę przypadku przeprowadzono dla spółki „Owoc Łącki”, w której poddano ocenie sposoby tworzenia wartości dodanej, formę integracji producentów owoców oraz współpracę z sieciami spożywczymi. 


\section{Istota i uniwersalizm pojęcia wartości dodanej}

W sprawnie funkcjonującym społeczeństwie każda dorosła i zdrowa osoba, uczestnicząc w różnorodny sposób w życiu społeczno-ekonomicznym, nie tylko konsumuje (aby żyć), ale także wnosi pewne nowe wartości poprzez produkcję, świadczenie usług komercyjnych, prace w sferze niematerialnej i kształcenie. Odbywa się to także poprzez udział w życiu rodzinnym i ekonomicznym gospodarstw domowych, wychowanie młodych pokoleń, opiekę nad chorymi, dziećmi itp. Zapewne część codziennych prac i obowiązków nie zawsze można nazwać twórczymi i oceniać, że wnoszą coś wielkiego lub że mają znaczący wpływ na rzeczywistość, ale są one dla ich interesariuszy ważne i wartościowe.

Wartość dodana w rolnictwie i ekonomii rolnictwa jest definiowana wielorako i najczęściej odnoszona do mikroekonomii, tj. przyrostu wartości dóbr lub produktu w wyniku określonego procesu produkcji czy też świadczenia różnego rodzaju usług. Jest to więc wartość nowo wytworzona, czyli dodana do już istniejącej wartości w wyniku produktywizacji pracy, zarówno fizycznej jak też i zarządczej, a także przy zastosowaniu dodatkowych materiałów i usług pochodzących od innych dostawców. W uproszczonym ujęciu rachunkowym stanowi różnicę pomiędzy przychodami ze sprzedaży a kosztem nabycia dóbr i usług zewnętrznych. Na wartość tę składają się płace (wynagrodzenia z tytułu dodania wartości), renty (korzyści ekonomiczne i pozaekonomiczne), zyski i procenty (Barro, 1997). Stanowi ona różnicę pomiędzy wartością (ceną) uzyskaną ze sprzedaży produktów a kosztami ich wytworzenia (Smid, 2012).

Wartość dodana w rolnictwie ujmowanym procesowo to portfel czy zespół praktyk rolniczych, które służą dostarczaniu produktu finalnego. W ujęciu mikroekonomicznym, gdy pojęcie to odnosimy do gospodarstw rolnych, wartość dodana w ujęciu brutto stanowi ogółem wartość produkcji podmiotu rolnego (gospodarstwa) skorygowaną o saldo dopłat i podatków. Oznacza ona przyrost wartości dóbr wytworzonych w danym gospodarstwie i świadczy o efektywności ponoszonych nakładów. Stanowi więc nadwyżkę ekonomiczną obliczoną jako różnica pomiędzy wartością produkcji gospodarstwa i wartością zużycia pośredniego skorygowaną o saldo dopłat i podatków. Odzwierciedla wówczas nie tylko nowo wytworzoną wartość w gospodarstwie przez trzy czynniki produkcji, tj. ziemie, pracę i kapitał, ale, z racji korekty o saldo bieżące dopłat i podatków, także wpływ państwa na politykę ekonomiczną, w jakiej wytwarzana jest produkcja rolna. Gdy od wartości dodanej brutto odejmiemy wartość zużytych środków trwałych (amortyzację), otrzymamy wartość dodaną netto. Poza opłatą zastosowanych czynników produkcji odzwierciedla ona także opłatę za nakłady pracy i zarządzanie (Goraj i in., 2004).

Ponadto wartość dodaną w ekonomii mierzyć można wielorako, rozwijając jej znaczenie, tj. zarówno jako stricte dodatkową moc (siłę) ekonomiczną firmy uzyskaną w wyniku pozytywnych procesów następstw czy skutków poprawy zarządzania, jak i odnosząc ją do społecznego wymiaru tych zmian, tj. np. do odczuć załogi firmy, wpływu firmy na otoczenie miejsca jej lokalizacji czy też wpływu na pozycję branży gospodarczej. Poszukując analogii w kreacji wartości dodanej do koncepcji siły w naukach o zarządzaniu, Milczarek-Andrzejewska (2014) zwraca uwagę, że podejście do rynku powinno mieć z zasady charakter interdyscyplinarny. Analiza jego siły i to zarówno po stronie podażowej, jak i popytowej powinna uwzględniać przesłanki przynależne naukom społecznym i humanistycznym, a także psychologii. O sile danego rynku, gdy odniesiemy ją do tworzenia wartości dodanej, decydują także: rzadkość oferowanego towaru oraz, a może nade wszystko, jakość informacji. Źródła siły w kreacji rynku, a więc w pozyskiwaniu 
poprzez rynek wartości dodanej, można dopatrywać się również w kombinacji takich składowych, jak siła zachęty (marketingu), wymuszania (pilności potrzeb), siła wynagradzania (osiąganych cen) oraz siła osiaganych korzyści (marży).

Za ważny poznawczo sposób uzyskania wartości dodanej w organizacji i zarządzaniu w rolnictwie oraz gospodarstwach rolnych można uznać synergię (efekty synergii). Synergia w ekonomii to efekt współpracy i optymalnej integracji różnych elementów, która umożliwia uzyskanie lepszego wyniku niż możliwy jest on do osiągnięcia w niezależnym działaniu (Domagalska-Grędys, 2012). Efekt synergii jest także swoistą nadwartością, czyli wartością dodaną uzyskaną $\mathrm{w}$ wyniku zmian organizacyjnych, np. nowej kombinacji czynników wytwórczych lub wyborze innej strategii działania w firmie czy na rynku (Toffler, 1986). Pojęcie wartości dodanej w powiązaniu ze zjawiskiem synergii rozumianej jako współpraca można odnieść także do połączenia wielu faz produkcji lub zaopatrzenia i obrotu, co może być istotne dla organizacji gospodarstw. Można wówczas uzyskać efekty ekonomiczne, które z reguły nie są dostępne dla firm czy gospodarstw działających samodzielnie. Wartość dodana wynikająca ze współpracy podmiotów gospodarczych łączona może być z synergią o charakterze operacyjnym. Mieszczą się tu różne formy współpracy czy też integracji o charakterze poziomym (pomiędzy podmiotami wytwarzającymi tożsame lub podobne produkty) lub pionowym, np. będące w różnych fazach produkcji i obrotu. Jej efekty, gdy są dodatnie (synergia dodatnia), stają się zamierzonymi celami stawianymi przez interesariuszy współpracy i są np. wzrostem obrotów, wartości produkcji, cen zbytu, zysków, wartości firm itp. (Kicińska, 1995).

W ekonomii za istotnego kreatora wartości dodanej uznaje się efekt skali. Jest on rozumiany wielorako, w tym głównie jako efekt techniczny lub efekt ekonomiczny. Jego istotą jest wykorzystanie techniki służącej bardziej efektywnemu lokowaniu nakładów, która przy produkcji na małą skalę nie byłaby możliwa. Korzyści te, czyli „przychody ze skali” lub wartość dodana osiagana przez zwiększenie skali, wynikają ze zwiększenia efektywności w odniesieniu do: relacji przyrostu produkcji do przyrostu nakładów, degresji kosztów zarządzania i amortyzacji. Po osiagnnięciu określonej dużej skali korzyści z reguły mają charakter wygaszający $\mathrm{i}$ mogą zamienić się $\mathrm{w}$ straty $\mathrm{z}$ racji nadmiernej $\mathrm{i}$ nieuzasadnionej ekonomicznie skali wytwarzania, nadmiernej koncentracji produkcji i stąd powstających różnorodnych problemów logistycznych (Kowalski, 1996).

Powstawania wartości dodanej o charakterze ekonomicznym można doszukać się także w tzw. korzyściach zakresu. Jest to podejście o charakterze produktowym, wskazuje na korzyści wynikające $\mathrm{z}$ oferowanego szerokiego asortymentu produkcji lub świadczonych usług. Korzyści te powstają nie poprzez skooperowanie podmiotów wytwarzających różne produkty, lecz poprzez połączenie wytwarzania w ramach jednej firmy, najczęściej kooperatywnej. Skutkuja one zmniejszaniem ryzyka rynkowego, lepszym wykorzystaniu zasobów pracy i kapitału oraz $\mathrm{w}$ oferowaniu kompleksowych produktów i usług (Domagalska-Grędys, 2012).

Wartość dodaną można także odnosić nie tylko do łączenia czynności i współdziałania podmiotów gospodarczych, ale także do współdziałania i efektów synergii w sferze społecznej. Współdziałanie o charakterze społecznym wyzwala dodatkową energię i efekty, które nie są możliwe (lub trudne) do osiagnięcia poprzez działania indywidualne. Wzmocnieniu ulegają tu nie tylko procesy, które można nazwać energetycznymi, ale także efekty informacyjne i samorealizacyjne jednostek w nich uczestniczących (Kornai, 1977). Aby osiagnąć wartość dodaną $\mathrm{w}$ ujęciu społecznym, istotne są także pozytywne determinanty sukcesu czy też kreacji wartości dodanej. Poza formalnymi wzorcami 
zachowań, jakie tworzą przepisy prawa, ważne są zachowania nieformalne, w tym dobre zwyczaje partnerów współpracy (kontrahentów), ale także tradycja oraz kultura zachowań indywidualnych i społecznych. Moga one determinować, sprzyjać, hamować lub zniechęcać do współpracy, której warunkiem wyjściowym jest postawa etyczna partnerów, ich uczciwość i wiarygodność (Nowicka-Skowron, 2000).

Współcześnie, $\mathrm{z}$ reguły osiagana $\mathrm{w}$ warunkach rynkowych, różnorodna wartość dodana, mierzona ilościowo, wartościowo lub w kategoriach ocen pozaekonomicznych, wywołana jest poprzez zachowania konkurencyjne występujące na rynku, realizowane poprzez interesariuszy zarówno po stronie podażowej, jak też i popytowej. Konkurencja ta wyzwalana jest głównie poprzez różnorodne wyzwania globalizacyjne. Małe firmy funkcjonujące niszowo swój rozwój mogą lub próbują opierać o efekt doświadczenia. Większe firmy, w tym także bardzo duże, z reguły próbują autorsko budować swój potencjał konkurencyjny, a więc osiagać wartość dodaną poprzez różnorodne formy współpracy z partnerami biznesowymi. Mogą wówczas efektywnie kumulować zasoby i kluczowe umiejętności czy kompetencje. Mają także dużo większe możliwości unikania lub obniżania różnorodnych kosztów transakcyjnych, np. na poziomie negocjacji, tworzenia rezerw czy logistyki. Zyskują przez to szanse na uzyskanie dodatkowej wartości, tj. wartości dodanej o charakterze ekonomicznym. Następuje to wskutek nawiązania uprzywilejowanych czy niekonkurencyjnych powiązań $\mathrm{z}$ dostawcami, odbiorcami lub dotychczasowymi konkurentami. Często procesom współpracy czy współdziałania o charakterze synergii towarzyszy powstawanie korzystnych relacji także w sferze spersonifikowanej. Wartością dodaną jest wówczas renta relacyjna, czyli korzyści nadzwyczajne $\mathrm{z}$ wymiany lub wspólnego zastosowania nowych informacji, zasobów, technologii, redukcji kosztów i ryzyka (Kulawik, 2010).

Pojęcie wartości dodanej można odnosić ponadto do szeroko rozumianej edukacji, $\mathrm{w}$ tym skierowanej do rolników, a tu jest ona $\mathrm{z}$ reguły trafnie rozpoznawana i rozumiana. Na etapie sformalizowanego kształcenia oznacza przyrost wiedzy i umiejętności ucznia (kursanta) wskutek zastosowania efektywnego procesu dydaktycznego. Skuteczność tego procesu można mierzyć poprzez różnorodne sprawdziany zdobytej wiedzy. Gdy wiedza dotyczy nauk stosowanych, np. zmian w technologii produkcji rolniczej, wówczas miarą wartości dodanej oraz sprawdzanej skuteczności kształcenia lub doradztwa rolniczego są wprowadzane i pozytywnie oceniane zmiany. Mogą one polegać na udoskonaleniach lub innowacyjnych rozwiązaniach, które spełniają kryterium celu, a więc zwiększają wielkość produkcji, jej jakość, dostępność, zmniejszają lub stabilizują koszty wytworzenia itp. Jest to pojęciowo bliskie wartości dodanej osiągniętej poprzez dobre zarządzanie organizacją procesem technologicznym, zasobami ludzkimi czy produktami finalnymi (Kania, 2017).

Wartość dodana na obszarach wiejskich może mieć także postać rent, czyli nadzwyczajnych korzyści wynikających $\mathrm{z}$ różnorodnych działań o charakterze instytucjonalnym. Wartością tą jest renta integracyjna, tj. wiązka płatności, z jakiej mogą skorzystać rolnicy, samorządy czy instytucje otoczenia instytucjonalnego wsi i rolnictwa. Wynika ona z członkostwa Polski w Unii Europejskiej i uczestnictwa w wspólnej polityce rolnej lub polityce strukturalnej. Polityki te maja, znane i ustalone poprzez procesy negocjacyjne na szczeblu UE oraz uszczegółowione na poziomie krajowym, cele, priorytety, instrumenty i środki finansowego wsparcia. Umożliwiają one prowadzenie opłacalnej i konkurencyjnej produkcji rolnej, zwłaszcza po osiagnięciu przez gospodarstwa określonej jej skali, sprzyjają unowocześnieniu gospodarstw poprzez wsparcie procesów inwestycyjnych. Wsparcie to (i to jest kwestia problematyczna) zmniejsza napór na 
przekształcenia agrarne i spowalnia koncentrację ziemi, ale także wpływa łagodząco na problemy społeczno-ekonomiczne wsi, zwłaszcza regionów rozdrobnionych agrarnie (Czyżewski, 2013).

Wartość dodana na obszarach wiejskich, a bezpośrednio lub pośrednio także W rolnictwie, może przyjmować również postać renty z ziemi, która powstaje lub może powstać poprzez działania planistyczne realizowane na szczeblu samorządu gminnego. Przekwalifikowanie formalne gruntu rolnego na nierolny o nowych funkcjach, zwłaszcza o przydatności do zabudowy mieszkalnej czy biznesowej, powoduje, szczególnie na terenach miejskich (np. w dużych miastach), wielokrotny wzrost ceny ziemi. Może stanowić to, w sytuacji zaistnienia transakcji kupna-sprzedaży, znaczący, dodatkowy przychód dla właściciela ziemi. Przychody te stanowią, w stosunku do wcześniej możliwych do uzyskania przychodów za sprzedaną ziemię, wartość dodaną. Może ona być przeznaczona na rozwój działalności rolniczej lub pozarolniczej albo na cele konsumpcji, wzmacniając ekonomię mieszkańców środowisk lokalnych (Musiał i Wojewodzic, 2014).

$\mathrm{Na}$ poziomie dokumentów podejmujących instytucjonalne aspekty integracji europejskiej funkcjonuje także (od niedawna) pojęcie europejskiej wartości dodanej (Śródokresowa ocena..., 2018). Pod pojęciem tym rozumie się korzyści, które można osiagnąć dla wspólnego dobra obszaru gospodarczego UE poprzez inwestowanie w badania naukowe i innowacje. Polegają one na zwiększeniu możliwości badawczych poprzez połączenie prywatnych i publicznych zasobów oraz wiedzy i tworzenie wielodyscyplinarnych sieci, łańcuchów wartości i rynków. Korzyści te powinny być także osiaggnięte poprzez współpracę i konkurencję w zakresie badań naukowych oraz wymianę wiedzy i transfery technologiczne. Innowacyjne projekty, angażujące przedstawicieli nauki, doradztwa, przedsiębiorstw pracujących na rzecz rolnictwa i rolników, mogące mieć natychmiastowe zastosowanie $\mathrm{w}$ praktyce, mają szanse pozyskać wsparcie w ramach PROW 2014-2020 (dz. Współpraca). Unia Europejska poprzez fundusze strukturalne i współfinansowanie programów operacyjnych jest także atrakcyjnym miejscem dla edukacji, badań naukowych, innowacji oraz przedsiębiorczości.

\section{Tworzenie wartości dodanej w rolniczym łańcuchu dostaw założenia teoretyczne}

Wartość dodana w łańcuchu dostaw żywności jest pojęciem odrębnym, stosowanym głównie dla celów oceny sprawności kanałów dystrybucji. Stanowi ona kolejno następujące po sobie lub ujmowane sumarycznie nowe wartości dodawane w procesie przemieszczania się produktu: od producenta surowców, poprzez przetwórcę, certyfikację, marketing i ostatecznie dystrybucję do konsumenta finalnego. Dla podmiotów uczestniczących w tym procesie przynoszą one zróżnicowane marże i zyski. Są one z reguły wzrastające w miare zbliżania się produktu w łańcuchu dostaw do klienta finalnego (Woś, 2004).

Powszechną regułą jest to, że producenci rolni otrzymują dużo mniejszą część pieniędzy wydatkowanych przez konsumentów na żywność niż producenci żywności finalnej, a zwłaszcza ci, którzy sprzedają produkty markowe. Przechwytywanie tych dodatkowych wartości z rynku, określanych jako wartości dodane w łańcuchu dostaw, jest celem wielu producentów..

Według definicji USDA (2015) produkt rolniczy, aby posiadał wartość dodaną powinien spełniać jedną z pięciu cech lub metod dodawania wartości, tj.: 
- przeszedł zmianę stanu fizycznego,

- został wyprodukowany w sposób, który zwiększa wartość surowca powstałego towaru rolniczego,

- jest fizycznie i instytucjonalnie klasyfikowany w sposób, który powoduje wzrost jego wartości,

- jest źródłem energii odnawialnej opartej na surowcach pochodzących $\mathrm{z}$ gospodarstwa,

- jest przygotowany i wprowadzony do obrotu jako lokalny produkt z oznaczeniami.

W wyniku zmiany stanu fizycznego lub tego, w jaki sposób produkt jest wytwarzany, konfekcjonowany i sprzedawany, powiększana jest oferta produktów rolniczych dla konsumentów. Z drugiej strony, większa część dochodów uzyskanych ze sprzedaży, przetwarzania i klasyfikowania pozostaje w gospodarstwie. Ta definicja USDA pomaga scharakteryzować strategie tworzenia wartości dodanej i uzasadnia kwalifikowalność dotacji z budżetu państwa czy UE na podejmowane inicjatywy w tym zakresie.

Inne definicje wartości dodanej dotyczą preferencji konsumentów oraz ekonomiki produkcji (Coltrain, Barton i Boland, 2000; Amanor-Boadu, 2003). Podkreślają one znaczenie maksymalizacji wewnętrznej efektywności gospodarstwa oraz oceny produkcyjnej i ekonomicznej wykonalności przed rozpoczęciem inicjatywy przedsiębiorczej w zakresie tworzenia wartości dodanej. Zwracają także uwagę na fakt, że strategie tworzenia wartości dodanej nie mają na celu jedynie zastappienia wydajnej (efektywnej) produkcji, a więc nie dotyczą tylko jej aspektów technologicznych. Coltrain, Barton i Boland (2000) definiują wartość dodana jako „proces ekonomicznego dodawania wartości do produktu poprzez zmianę jego obecnego miejsca, czasu i formy na cechy bardziej preferowane na rynku”. Ostatecznym źródłem dyskontowania wartości jest konsument, który płaci za produkty rolne lub spożywcze na rynku. Zwiększanie wartości dodanej w rolnictwie można więc osiągnąć tylko wtedy, gdy rolnicy będą w stanie dostarczyć na rynek produkty w formie, przestrzeni, czasie, jakości, funkcjonalności i cechach tożsamości, za które konsumenci będą gotowi zapłacić wyższą cenę niż za surowce podstawowe bez tych cech.

Ekonomiści i decydenci w USA często opisują wartość dodaną jako wkład firmy w produkt regionalny brutto (Gross Regional Product - GRP). Oparta na GRP definicja wartości dodanej uwzględnia zwiększoną efektywność produkcji towarowej jako praktykę tworzenia wartości dodanej, ale nie uwzględnia żadnej z pięciu wyznaczników USDA dodawania wartości.

Wartość dodana na poziomie gospodarstwa lub firmy nie może przełożyć się na wyraźnie wyższy GRP, jeśli sprzedawany on jest poza regionem. Wymagałoby to redystrybuowania wartości od przetwórców do producentów na poziomie zagregowanym. $\mathrm{Na}$ rycinie 1 zilustrowano różnice między dwoma rodzajami podejścia do tworzenia wartości dodanej w rolnictwie. Tradycyjnie wartość dodana jest przechwytywana i tworzona przez podążanie ścieżką (po lewej stronie ryciny 1), w której rolnicy uczestniczą w etapach wykraczających poza produkcję i sprzedaż surowców w łańcuchu dostaw produktów rolnych, takich jak przekształcanie produktu, dystrybucja, przechowywanie i dodatkowe usługi. 


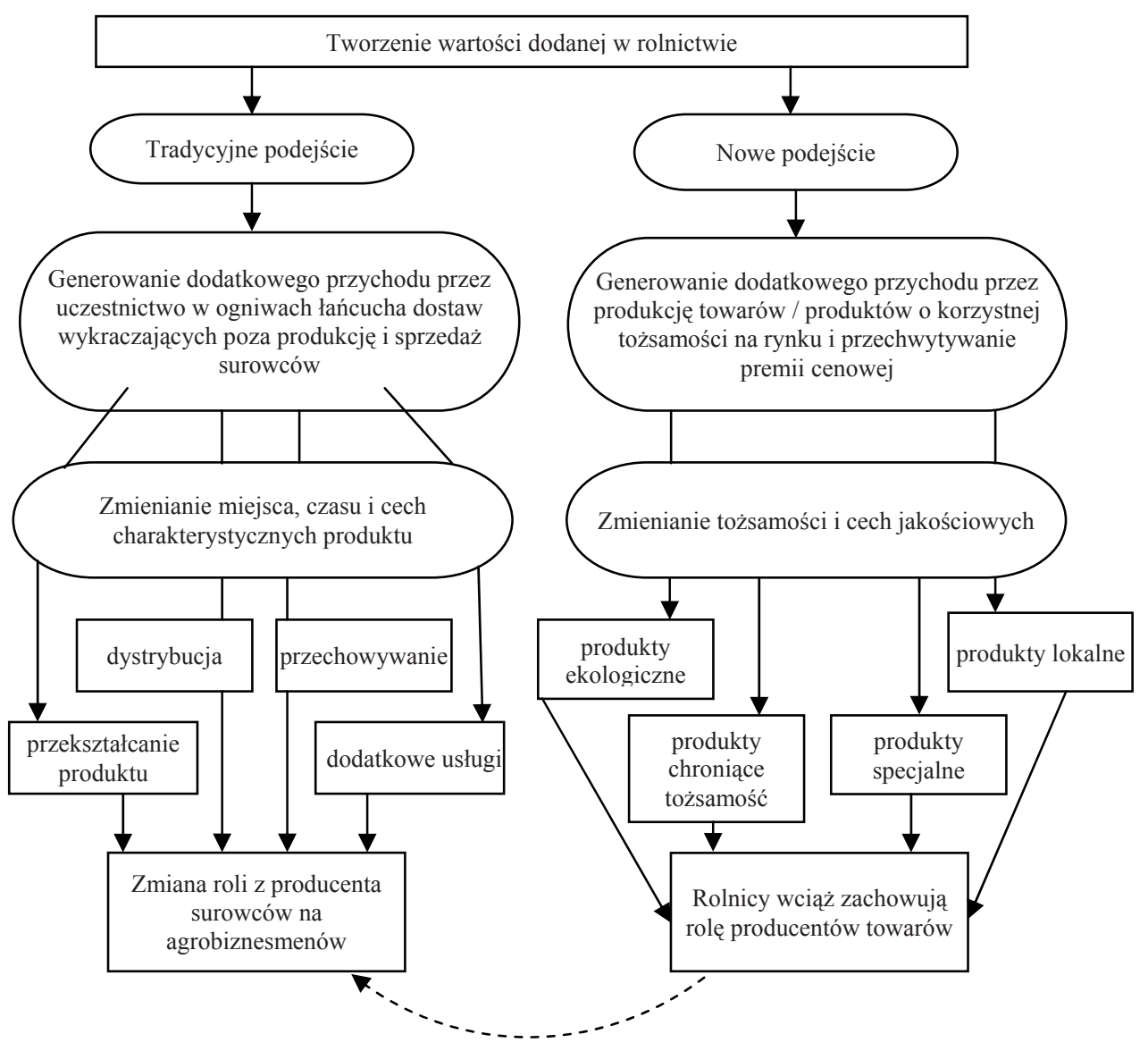

Rys. 1. Tradycyjne i nowe aspekty tworzenia wartości dodanej w rolnictwie

Fig. 1. Traditional and New Aspects of Added Value Creation in Agriculture

Źródło: Opracowanie własne na podstawie: Lu i Dudensing, 2015, Ernst i Wood, 2011.

Rola rolników w tym podejściu zmienia się od producentów surowców do agrobiznesmenów o rozszerzonych możliwościach. Odzwierciedleniem tego podejścia może być grupa producentów owoców i warzyw „Owoc Łącki” (Kania i Musiał, 2017).

Nowe podejście na rynkach rolnych (po prawej stronie ryc. 1) i najlepsze praktyki produkcyjne umożliwiają rolnikom zwiększanie wartości ich produktów poprzez selekcjonowanie produktów i podnoszenie ceny w oparciu o cechy ich tożsamości, w tym lokalne, geograficzne lub ekologiczne oznaczenia (Womach, 2005, Ernst i Wood, 2011). Te dwa rodzaje wartości dodanej nie wykluczają się nawzajem, a rolnicy mogą łączyć dobre praktyki z obu ścieżek.

Niezależnie od stosowanego podejścia w tworzeniu wartości dodanej, podjęte działania powinny poprawić rentowność lub zmniejszyć ryzyko dla pojedynczego gospodarstwa. Ryzyko jest zazwyczaj niższe, gdy dodatkowa wartość jest tworzona poprzez oferowanie na rynku produktów o cechach cenionych przez konsumentów, niż 
kiedy wartość dodana jest przechwytywana przez zmianę rozkładu wartości w łańcuchach dostaw (Brees, Parcell i Giddens, 2010). Niezależnie od tego producenci muszą nieustannie utrzymywać przewagi konkurencyjne, takie jak bycie producentem nisko kosztowym lub pierwszym, który stosuje nowe praktyki produkcyjne lub gwarantuje najbardziej wiarygodne dostawy itp. Tu już wykraczamy poza wskazane powyżej definiowanie i opisywanie procesu podwyższania wartości dodanej, co daje pole do rozszerzenia tego pojęcia i poszukiwania analogii na nowych polach opisu i diagnozy skutecznych zmian przynoszących wymianę korzyści dla producentów, przetwórców, ogniw pośredniczących w dystrybucji i końcowych nabywców czy też konsumentów.

Lu i Dudensing (2015) uwzględniając powiązania między przewaga konkurencyjną rolników, praktykami tworzenia wartości dodanej i zmieniającymi się preferencjami konsumentów w zakresie produktów rolno-spożywczych, proponują jedno lub więcej $\mathrm{z}$ następujących trzech podejść tworzenia wartości dodanej $\mathrm{w}$ oparciu o posiadane możliwości i zasoby:

- wykonywanie dotychczasowej tradycyjnej działalności rolniczej, ale na innym, wyższym etapie łańcucha dostaw, który zmienia charakterystykę formy, miejsca i czasu oferowanych na rynku produktów rolnych (produktów vs surowców) np. sprzedaż mąki zamiast ziarna pszenicy i żyta, selekcjonowanie, pakowanie i konfekcjonowanie produktów oraz ich dostawa bezpośrednio do punktów sprzedaży, magazynowanie i przechowywanie produktów do sprzedaży w późniejszym czasie, produkcja biopaliw;

- pionowa integracja kilku etapów łańcucha dostaw lub pozioma koordynacja z innymi rolnikami lub omijanie etapów łańcucha dostaw, aby stworzyć bliższe lub bezpośrednie połączenie między rolnikami a konsumentami, np.: łączenie istniejących kanałów zbytu, tworzenie rynków hurtowych i lokalnych targowisk;

- prowadzenie działalności lub przyjmowanie praktyki produkcyjnej na etapie wzrostu jej wartości, która zmienia cechy tożsamościowe lub jakościowe surowcowych produktów rolniczych na cechy, które konsumenci cenią sobie najwyżej na rynku, np.: produkcja ekologiczna, produkcja jaj i kurczaków z hodowli zagrodowej kur, produkcja własna przetworów mlecznych, mięsnych i owocowych.

\section{Analiza przypadku}

W tworzeniu wartości dodanej w polskim rolnictwie uwzględnia się niemal wszystkie wcześniej prezentowane podejścia, w upowszechnianiu których ogromną rolę odgrywają ośrodki doradztwa rolniczego, izby rolnicze, organizacje pozarządowe oraz w coraz większym stopniu prywatne firmy konsultingowe. Przykładami są powstałe w ostatnich dwudziestu latach zespoły producentów rolnych i grupy marketingowe, ale także rozwój sprzedaży bezpośredniej produktów rolnych, mniej lub bardziej przetworzonych na miejscu u rolnika lub z dostawą do domu, produktów ekologicznych i funkcjonalnych, sprzedaż internetowa itp. Przykład tworzenia wartości dodanej obejmujący wszystkie ogniwa łańcucha marketingowego można syntetycznie zilustrować na przykładzie sądeckiej Grupy Producentów Owoców i Warzyw „Owoc Łącki” (GPOiW).

GPOiW została zarejestrowana 2 lipca 2003 roku jako spółka z ograniczoną odpowiedzialnością. Początkowo w skład Grupy wchodziło 17 członków, w tym jeden z nich to osoba prawna - Sadowniczy Zakład Doświadczalny w Brzeznej Sp. z o.o., a 
wspólna powierzchnia sadów wynosiła około 100 ha. W 2018 roku GPOiW nadal liczy 17 członków, ale ma ponadto 93 udziałowców i ponad 350 ha sadów. Swoją siedzibę ma w Łącku w powiecie Nowy Sącz i zatrudnia obecnie ponad 70 pracowników (Kania, Musiał, 2017).

W badanej Grupie stwierdzono trzy innowacyjne rozwiązania organizacyjne umożliwiające tworzenie wartości dodanej. Po pierwsze, to instytucjonalna i realna integracja pozioma rolników-sadowników przez podjęcie współpracy i utworzenie grupy producentów rolnych. Sprzyja to wprowadzaniu nowych odmian owoców, nowych technologii produkcji, poprawie jakości produktów i osiaganiu lepszych efektów ekonomicznych. Ponadto integracja pozioma przyczyniła się do lepszego wykorzystywania posiadanych zasobów i stworzyła możliwość korzystania $\mathrm{z}$ zewnętrznych źródeł finansowania (inwestycje w ramach PROW 2007-2013, MRPO 2007-2013 i kredyty). Po drugie, integracja pionowa, tj. rozszerzenie działalności GPOiW przez dywersyfikację „wprzód”, polegającą na przetwarzaniu jabłek na soki i koncentrat jabłkowy (zakład w Olszanie), wybudowaniu przechowalni owoców (zakład w Łącku) umożliwiającej sprzedaż w długim okresie (39 komór chłodniczych z kontrolowaną atmosferą, w każdej mieści się 170 t jabłek). Dokonano także zakupu linii do pakowania jabłek i dostarczania ich do sieci sklepów własnym nowoczesnym transportem. Po trzecie, nastapiło wyeliminowanie wszystkich pośredników z łańcucha dostaw zarządzanego przez GPOiW (Kania, Musiał, 2018).

Kreacja wartości dodanej w GPOiW odbywa się dzięki wielu różnorodnym działaniom. Punktem wyjściowym w sposobach tworzenia wartości dodanej jest dywersyfikacja produktów, takich jak owoce, soki tłoczone i koncentraty. Wśród owoców głównymi produktami są różne odmiany jabłek (Szampion, Jonagold, Jonagored, Idared, Gala, Rubin, Ligol, Boskoop, Golden, Elise) i gruszek (Konferencja, Lukasówka, Concorde, Bonkreta) oraz owoce sezonowe (czarna i czerwona porzeczka, maliny, aronia, śliwki, wiśnie, truskawki). Nowe nasadzenia sadów uwzględniają odmiany jabłek o zielonej jednolitej skórce, preferowane na rynkach krajów zachodnich. Oferta soków obejmowała soki: jabłkowy, jabłkowo-gruszkowy, jabłko i czarna porzeczka, jabłkowomarchwiowy, jabłko i czerwona porzeczka, jabłkowo-wiśniowy, jabłkowo-aroniowy i jabłkowo-bananowy. Dostępne opakowania to karton 5- i 3-litrowy, a wielkości te adresowane są do konkretnej grupy odbiorców, zarówno instytucjonalnych, jak i konsumentów indywidualnych. Koncentraty są produkowane jako naturalne zagęszczone soki owocowe uzyskane $\mathrm{w}$ procesie odparowania wody z soku świeżych owoców. Nie zawierają konserwantów, dlatego łączą wysokie walory smakowe i zdrowotne oraz nadają się do bezpośredniego spożycia po uprzednim rozcieńczeniu. GPOiW w szczególny sposób dba o wysoką jakość produktów. Stosowana technologia produkcji soków nie zawiera dodatków, takich jak cukier, woda, aromat i kwas. Zabezpieczenie trwałości oparte jest na jednej z najbardziej sprawdzonych metod, czyli pasteryzacji (GPOiW posiada certyfikaty Global G.A.P, HACCP, IFS Food Certificate i Certificate-BRC). Dzięki nowoczesnym komorom chłodniczym z kontrolowaną atmosferą możliwe jest zachowanie wysokich walorów odżywczych i smakowych. Komory te mieszczą 7000 t owoców. GPOiW bardzo dużą uwage zwraca na działania logistyczne. Ułatwia to posiadanie nowoczesnej linii sortowniczej. Jabłka pakowane są zgodnie z życzeniami tzw. małych i dużych odbiorców. Używane są do tego różnego rodzaju kartony, wytłoczki, opakowania własne zamawiającego oraz różnej wielkości woreczki foliowe. Soki tłoczone pakowane są w worki bag In box ze specjalnym zaworem VITPO pozwalającym na wielokrotne 
dozowanie, a przydatność do spożycia po otwarciu worka wynosi 14 dni. Na sukces GPOiW składa się wiele przemyślanych i sprawdzonych działań, jednak bez wątpienia kluczową rolę odgrywają zdywersyfikowani odbiorcy. Są nimi sieci sklepów: Biedronka, Tesco, Lidl, Eurocash, Real, hurtownicy, sklepikarze oraz własne sklepy. Własne sklepy zlokalizowane są w Łącku i Nowym Sączu, a w nich oferowane są również produkty wytwarzane przez mieszkańców regionu (miody, produkty pszczele, serki górskie itp.). Grupa realizuje również eksport swoich produktów na rynki zagraniczne. Budowanie marki to różnorodne działania, które zapewniają rozpoznawalność i wysoki image. Jabłka Łąckie wpisane są na listę UE w obszarze chronionych geograficznie produktów rolnych. Produkowane tam owoce cechują się wyjątkową soczystościa, jędrnością i aromatem, co zawdzięczają mikroklimatowi Kotliny Łąckiej (6 km długości i $1,5 \mathrm{~km}$ szerokości). Ich rumieniec, zdaniem respondentów, jest mocniejszy od rumieńca jabłek pochodzących z innych regionów (Kania, Musiał, 2017).

Badany przypadek GPOiW „Owoc Łącki” jest przykładem przechwytywania wartości dodanej z rynku przez wyeliminowanie pośredników, tj. przetwórców, hurtowników i firm logistycznych. Stanowi model biznesowy, który obejmuje cały łańcuch dostaw od pola do półki sklepowej, tj. produkcję jabłek, przechowywanie, konfekcjonowanie i dostarczanie do sieci sklepów bądź przetwarzanie na soki i koncentrat jabłkowy. Rolnicy, członkowie grupy, mając do dyspozycji cały łańcuch marketingowy, stali się przedsiębiorcami agrobiznesmenami. Grupa ta stanowi zarazem cenny i unikalny przykład integracji pionowej „w przód”, a nie tylko integracji poziomej, w ramach której zazwyczaj powstają i prowadzą swoją działalność grupy producentów w branży owocowo-warzywnej, zbożowej, trzody chlewnej i innych w naszym kraju.

\section{Podsumowanie}

Termin ekonomiczny, czy też określenie „wartość dodana” w polskiej literaturze przedmiotu ma dość zawężone znaczenie i odnoszone jest zwykle do mikroekonomii, w tym rozliczania $w$ ramach podstawowych kategorii ekonomicznych i wynikowych przedsiębiorstw. Określenie to ma jednak znaczącą siłę wyrazu, wskazując na pozytywny aspekt opisu wyników procesów gospodarczych czy zjawisk dotyczących sfery ekonomii i nauk pokrewnych, a zwłaszcza zarządzania. Stąd zasadne jest, aby zostało szerzej włączone $\mathrm{w}$ opis różnych procesów i zjawisk, w tym także odnoszących się do sfery rolnictwa oraz rozwoju obszarów wiejskich. W opracowaniu wskazano na wielość i różnorodność definiowania i opisu uwarunkowań tworzenia wartości dodanej, odnosząc ją do ekonomiki rolnictwa i gospodarstw oraz obszarów wiejskich. W odniesieniu do zarządzania firmą poszukiwano analogii tego pojęcia z dodatkową siłą firmy uzyskaną wskutek następstw wynikających z poprawy w sferze nie tylko ekonomicznej, ale także w odniesieniu do aspektów społecznych. Podjęto problem omówienia osiagania wartości dodanej poprzez optymalną integrację różnych czynników czy elementów zarządzania i opisywanej jako efekt synergii. Zwrócono uwage, że w ekonomii za istotnego kreatora wartości dodanej dla firm można uznać tzw. efekt skali, ale także korzyści zakresu wynikające np. ze skooperowania firm. Współdziałanie podmiotów gospodarczych, zarówno w sferze ekonomii, jak i w sferze społecznej czy też interpersonalnej to kolejny obszar tworzenia wartości dodanej. Nazwą „,dodana wartość” można także określić wartości osiągane poprzez edukację lub doradztwo, które mogą być tanią i efektywną formą 
poprawy jakości produkcji i innowacji technologicznych, produktowych, marketingowych czy organizacyjnych. Wartość dodana w rolnictwie i na obszarach wiejskich może też mieć postać rent, czyli nadzwyczajnych korzyści osiąganych poprzez różnorodne przedsięwzięcia, które odnieść można do sfery instytucjonalnej. Jest to tworzenie wartości dodanej rozumianej jako dodatkowa korzyść osiagana przez rolników z tytułu uczestnictwa we wspólnej polityce rolnej czy też działania planistyczne „dodające wartości” (podwyższające cenę) ziemi z racji jej odrolnienia i przeznaczenia na cele nierolnicze.

Oddzielnie i szerzej potraktowano problem tworzenia wartości dodanej w łańcuchu dostaw i miejsca w tym procesie gospodarstw rolnych, które muszą wykorzystywać różne metody i podejścia przechwytywania tej wartości z rynku, zwiększając w ten sposób swoje dochody. Dobre przykłady i praktyki zilustrowane funkcjonowaniem grupy producentów „Owoc Łącki” stanowić mogą inspirację dla innych organizacji poszukujących nowych modeli biznesowych opartych na podnoszeniu wartości dodanej.

\section{Literatura}

Barro, R. (1997). Makroekonomia (Macroeconomics). PWE, Warszawa.

Coltrain, D., Barton, D., Boland, M. (2000). Value Added: Opportunities and Strategies. Arthur Capper Cooperative Center, Department of Agricultural Economics, Kansas State University. Pobrano z: http://www.agecon.ksu.edu/accc/kcdc/pdf\%20Files/VALADD10\%202col.pdf.

Czyżewski, B. (2013). Renty ekonomiczne w gospodarce żywnościowej w Polsce (Economic Retirements in the Food Economy in Poland). PWE, Warszawa.

Domagalska-Grędys, M. (2012). Rozwój gospodarstw rolnych poprzez działania grupowe producentów (Development of Farms through Group Activities of Producers). Zeszyty Naukowe UR w Krakowie. Rozprawy, zeszyt 363

Ernst, M., Woods, T. (2011). “Adding Value to Plant Production-An Overview.” Cooperative Extension Service, College of Agriculture, University of Kentucky. http://www.uky.edu/Ag/CCD/vaoverview.pdf.

Goraj, L., Mańko, S., Sass, R., Wyszkowska, Z. (2004). Rachunkowość rolnicza (Agricultural Accounting). Wyd. II, Difin, Warszawa.

Inteligentne i konkurencyjne łańcuchy dostaw żywności i napojów (Smart and Competitive Food and Drink Supply Chains). Przegląd Obszarów Wiejskich UE nr 22. Europejska Sieć Rozwoju Obszarów Wiejskich UE.

Kania, J., Musiał, W. (2017). Dodawanie wartości w łańcuchach dostaw żywności - studium przypadku (Adding Value In Food Supply Chains - case study). Roczniki Naukowe SERiA, 19(6), 133-138.

Kania, J. (2007). Doradztwo rolnicze w Polsce w świetle potrzeb i doświadczeń zagranicznych (Agricultural Extension in Poland in the Light of Needs and Foreign Literature). Zeszyty Naukowe AR w Krakowie, nr 440, Rozprawy z. 318.

Kicińska, B. (1995). Motywy łączenia się przedsiębiorstw (Themes of Business Mergers). W: Studia nad rozwojem przedsiębiorstw (Studies on Business Development). Praca zbiorowa pod red. E. Kurtysa. Zeszyty Naukowe AE w Poznaniu nr 225, 108-117.

Kornai, J. (1977). Teoria systemów gospodarczych. Kierunki badań (Theory of Economic Systems. Directions of Research) PWN, Warszawa.

Kowalski, Z. (1996). Efekt skali a efektywność technologii i poziom zarządzania w rolnictwie (Economies of Scale and Efficiency of the Technology and Management Level in Agriculture). Wydawnictwo ATR w Bydgoszczy. Monografia nr 69.

Kulawik, J. (2009). System monitorowania efektywności i produktywności przedsiębiorstw rolniczych (A System for Monitoring the Efficiency and Productivity of Agricultural Enterprises). Zagadnienia Ekonomiki Rolnej, 3, 33-49.

Lu, R., Dudensing, R. (2015). "What Do We Mean by Value-added Agriculture?" Choices. Quarter 4. Pobrano z: http://www.choicesmagazine.org/choices-magazine/submitted-articles/what-do-we-mean-by-value-addedagriculture. 
Milczarek-Andrzejewska, D. (2014). Zagadnienie siły w ekonomii - na przykładzie sektora rolno-spożywczego w Polsce (The Issue of Strenght in Economics - on the Example of the Agri-food Sector in Poland). IRWiR PAN, Warszawa.

Musiał, W., Wojewodzic, T. (2014). Innowacyjność w zakresie gospodarowania ziemią rolniczą w regionach rozdrobnionych agrarnie (Innovation in the Management of Agricultural Land in Agrarian Fragmented Regions). Prace Naukowe UE we Wroctawiu, 361, 162-168.

Nowicka-Skowron, M. (2000). Efektywność systemów logistycznych (Efficiency of Logistic Systems). PWE, Warszawa.

Smid, W. (2012). Boss Leksykon (Boss Lexicon). Wydawnictwo Dr Lex, Kraków.

Śródokresowa ocena programu „Horyzont 2020”: zwiększanie wpływu badań i innowacji w UE (Mid-term Evaluation of Horizon 2020: Increasing the Impact of Research and Innovation in the EU), (2018). Komunikat Komisji do Parlamentu Europejskiego, Rady, Europejskiego Komitetu Ekonomiczno$\begin{array}{lllllll}\text { Społecznego } & \text { i Komitetu } & \text { Regionów. } & \text { Pobrano } & 11 & \text { stycznia } & 2018\end{array}$ https://ec.europa.eu/transparency/regdoc/rep/1/2018/PL/COM-2018-2-F1-PL-MAIN-PART-1.PDF

Toffler, A. (1986). Trzecia fala (The Third Wave). PIW, Warszawa.

U.S. Department of Agriculture Rural Business-Cooperative Service (2015). Value-Added Producer Grant Program, Final Rule, 7 CFR Part 4284, Federal Register, Vol. 80, No. 89. Pobrano z: http://www.gpo.gov/ fdsys/pkg/FR-2015-05-08/pdf/2015-10441.pdf.

Womach, J. (2005). Agriculture: A Glossary of Terms, Programs, and Laws, 2005 Edition. Congressional Research Service, Library of Congress, Washington, DC. Pobrano z: http://digital.library.unt.edu/ark:/67531/metacrs7246/m1/1/high_res_d/97-905_2005Jun16.pdf.

Woś, A. (2004). W poszukiwaniu modelu rozwoju polskiego rolnictwa (In the search for a model of development of Polish agriculture). IERiGŻ, Warszawa, 86-98.

Do cytowania / For citation:

Kania J., Musiał W. (2018). Istota kreacji wartości dodanej w rolnictwie i na obszarach wiejskich. Problemy Rolnictwa Światowego, 18(2), 117-129; DOI: 10.22630/PRS.2018.18.2.39

Kania J., Musiał W. (2018). The Essence of Creating Value-Added in Agriculture and in Rural Areas (in Polish). Problems of World Agriculture, 18(2), 117-129; DOI: 10.22630/PRS.2018.18.2.39 